\title{
Investigation of diseases that cause diagnostic difficulty for Japanese general physicians
}

\author{
Tomoko Tsukamoto ${ }^{*}$ Yoshiyuki Ohira, Kazutaka Noda, Toshihiko Takada, Takanori Uehara and Masatomi Ikusaka
}

\begin{abstract}
Background: There have been some studies of common primary care diseases in Japan, but no reports on which diseases it is difficult for general physicians to diagnose in daily practice. In this study, we identified diseases that provided a diagnostic challenge for Japanese general physicians in daily practice.

Methods: The subjects were new undiagnosed patients referred to the General Outpatient Department of Chiba University Hospital during the one-year period from January 2008. We performed a retrospective chart review to identify the referring doctor, patient demographics, the duration of symptoms, the final diagnosis, and the outcome. Final diagnoses were classified according to the International Classification of Primary Care Second Edition (ICPC-2). In addition, the differences between referrals from general physicians and those from other physicians were assessed. Fisher's exact test and the Bonferroni-Holm correction were used for statistical analysis.

Results: A total of 169 patients were referred by general physicians and 239 patients were referred by other physicians. The most common ICPC-2 diagnosis was "General \& Unspecified" conditions (35 patients, 20.7\%), followed by "Psychological" conditions (31 patients, 18.3\%) and "Musculoskeletal" conditions (21 patients, 12.4\%). No significant differences of the ICPC-2 category for the final diagnosis and each diagnosis were found between patients referred by general physicians and those referred by other physicians. The hospitalization rate was lower for patients referred by general physicians than for patients referred by other physicians ( 4 patients, $2.4 \%$ vs. 24 patients, 10.0\%) $(P=0.002)$.

Conclusions: Japanese general physicians found difficulty in diagnosing "Psychological" conditions, "Musculoskeletal" conditions, variations within the normal range, and viral infections that required diagnosis by exclusion. Because most of the patients referred by general physicians had mild conditions, further education at outpatient departments and clinics is required to improve diagnostic performance. Additionally, it is important to increase the gatekeeper role of general physicians and further development of the medical system by the government to distinguish the functions of clinics and hospitals is expected.
\end{abstract}

Keywords: General physician, Referred patient, Final diagnosis, Diagnostic difficulty

\section{Background}

All citizens in Japan are covered by a national health insurance system in which there are no official "gatekeepers". Patients can freely choose between attending a local physician's office (clinic) or a hospital and Japanese physicians can freely practice internal medicine [1]. But recently, Japan has faced the problems of a rapidly aging population, financial constraints, and both a shortage and unbalanced distribution of doctors, with the need to

\footnotetext{
* Correspondence: toko@ra3.so-net.ne.jp

Department of General Medicine, Chiba University Hospital, 1-8-1 Inohana, Chuo-ku, Chiba, Chiba pref 260-8677, Japan
}

improve the primary care system and delivery of general medicine being pointed out [2]. Primary care physicians are expected to perform a wide range of roles, such as management and prevention of common diseases, and one of their vital tasks is to detect patients with serious diseases among the many patients they encounter in daily practice $[3,4]$. Patients who present to general practitioners are often at an early stage in the natural history of their disease and have vague, atypical or confusing symptoms, resulting in a wide range of diagnostic possibilities [5]. In Japan, general physicians can refer their patients to specialists at any medical institutions for 
diagnosis or treatment with a referral letter. When patients visit an advanced treatment hospital without referral from a primary care physician, they have had to pay an additional charge since 1996 [6,7].

There have been some studies of common primary care diseases in Japan, but no investigations into which diseases present diagnostic difficulty for general physicians working in community based primary care $[8,9]$. Chiba University Hospital is located in the western part of Chiba Prefecture near Tokyo, and is a tertiary medical institution with 36 specialist departments that is designated as an advanced treatment hospital. In the present study, we investigated the final diagnoses of patients referred to the General Medicine Department to determine the diseases that are difficult for Japanese general physicians to diagnose in daily practice. We also assessed the differences between referrals from general physicians and those from other physicians.

\section{Methods}

\section{Subjects}

The subjects were new patients who were referred to the General Medicine Department of Chiba University Hospital for diagnosis during the one-year period from January 2008. Their medical records were retrospectively reviewed and information was stored in a database. The following data were collected: the referring doctor, patient demographics (age and sex), the duration of symptoms, the final diagnosis, the final diagnostic category according to the International Classification of Primary Care Second Edition ("ICPC-2"), and the presence/absence of specialist treatment and hospitalization after diagnosis. The General Medicine Department is part of the Internal Medicine Department, and staff physicians provide initial treatment for patients who present during office hours after referral from other departments of the hospital or from other medical centers, including those of general physicians. In Japan there is no official recognition of "family physicians" or "general practitioners" by the government. Accordingly, we categorized physicians working at general internal medicine clinics as "general physicians" and physicians working at specialist clinics or hospital physicians as "other physicians".

\section{Diagnosis}

At our department, the diagnosis was made by a team of 3 staff physicians who assessed each new patient. If it was difficult to make a diagnosis, a medical board was held at the department and we referred the patient to an appropriate specialist, if necessary. Diagnoses that were assigned to categories without specific findings, such as unspecified viral infections and adverse reactions to medications, were only made after taking a detailed history and performing physical examination, blood tests, and imaging as required. For psychiatric diseases, the diagnosis was made by consensus of two physicians from the General Medicine Department after careful investigation to detect any physical disease. If making a diagnosis was difficult, we referred the patient to a psychiatrist. After checking the initial diagnosis and medical records over a 1-year follow-up period, the latest diagnosis was selected as the final one. If there was more than one diagnosis, the principal diagnosis was defined as the final diagnosis.

\section{Ethics}

Patient numbers were coded for information processing and were destroyed upon completion of the investigation. Since the names were not attached to the information, individual patients could not be identified. This study received approval from the Chiba University Graduate School of Medicine Ethics Board (number 1057).

\section{Statistical analysis}

Differences of the ICPC-2 diagnostic classifications, the final diagnosis, and the presence/absence of specialist treatment and hospitalization between patients referred by general physicians and by other physicians were assessed for statistical significance using Fisher's exact test, and the level of significance was set at $\mathrm{P}<0.05$ for each analysis. Because analysis of the ICPC-2 category (18 categories) and the final diagnosis (38 diseases) involved multiple comparisons, correction was done by a post hoc Bonferroni test and the level of significance was set at $\mathrm{P}<0.0028$ and $\mathrm{P}<0.0013$, respectively. Compilation of data and calculation of descriptive statistics were performed with SPSS for Windows (version 17.0).

\section{Results}

\section{Referring doctor}

A total of 10,260 new patients presented to the internal medicine departments of Chiba University Hospital during the study period. Among these patients, 1,402 presented to the General Medicine Department and 408 (29.1\%) of them were referred to us without diagnosis. Among these 408 patients, 169 (41.4\%) were referred by general physicians and 239 (58.6\%) were referred by other physicians (Table 1).

\section{Demographics and duration of symptoms of the patients referred for diagnosis}

The 169 patients who were referred by general physicians included 60 men (35.5\%) and 109 women (64.5\%). Their median age was 52 years (range: 16-86 years), and the median interval from the onset of symptoms until referral to our department was 60 days (range:1-3650 days). These results were similar to those for the patients referred by other physicians (Table 2). 
Table 1 Referring doctors for the $\mathbf{4 0 8}$ patients who were referred to the General Medicine Department for diagnosis $(n=408)$

\begin{tabular}{ll}
\hline General physicians & $169(41.4 \%)$ \\
Other physicians & $239(58.6 \%)$ \\
Specialist departments at our hospital & $119(29.2 \%)$ \\
Local/general hospitals & $79(19.4 \%)$ \\
Specialist clinics & $30(7.4 \%)$ \\
Other university hospitals & $8(2.0 \%)$ \\
More than one hospital & $3(0.7 \%)$
\end{tabular}

General physicians: physicians working at general internal medicine clinics. Other physicians: physicians working at specialist clinics or hospital physicians. Our hospital: Chiba University Hospital.

\section{Final diagnosis}

When the final diagnosis was classified by organ system according to ICPC-2, patients referred by general physicians most commonly had "General \& Unspecified" conditions (35 patients, 20.7\%), followed by "Psychological" conditions in 31 patients (18.3\%), "Musculoskeletal" conditions in 21 patients (12.4\%), and "Digestive" conditions in 20 patients $(11.8 \%)$. When the patients were analyzed according to the referring physician, the three common categories were the same, and there was no significant difference of each category between the two groups according to Fisher's exact test with a post hoc Bonferroni test (Table 3).

Among final diagnoses in the category of "General \& Unspecified" conditions for patients referred by general physicians, 9 patients had unspecified viral infections, 8 patients were found to be normal, and 8 patients had adverse reactions to medications. Among the patients who were diagnosed as actually being normal, the main complaint was low-grade fever in 4 patients who were concerned about serious diseases and had no abnormalities on testing. Their symptoms improved after they were reassured that there were no abnormalities. "Psychological" conditions included anxiety disorder in 9 patients, mood disorder in 6 patients, adjustment disorder in 5 patients, and somatoform disorder in 4 patients. In two patients, a final diagnosis could not be made. Both were referred to our department with fever of unknown origin. One patient

Table 2 Demographics and duration of symptoms for patients referred to the General Medicine Department for diagnosis $(n=408)$

\begin{tabular}{lll}
\hline & $\begin{array}{l}\text { Referred by general } \\
\text { physicians }(\mathbf{n = 1 6 9 )}\end{array}$ & $\begin{array}{l}\text { Referred by other } \\
\text { physicians }(\mathbf{n = 2 3 9})\end{array}$ \\
\hline Sex-Male/Female & $60 / 109$ & $104 / 135$ \\
$\begin{array}{l}\text { Median age (range) } \\
\text { Median duration of }\end{array}$ & 60 days (1-3650 days) & 60 days (1-10950 days) \\
symptoms (range) & & 55 years (16-97 years) \\
\hline
\end{tabular}

General physicians: physicians working at general internal medicine clinics. Other physicians: physicians working at specialist clinics or hospital physicians.
Table 3 International classification of primary care second edition (ICPC-2) category of the final diagnosis of patients referred to the General Medicine Department ( $n=408)$

\begin{tabular}{|c|c|c|c|}
\hline \multirow[t]{2}{*}{$\begin{array}{l}\text { ICPC-2 organ } \\
\text { system category }\end{array}$} & \multirow{2}{*}{$\begin{array}{l}\text { Referred } \\
\text { by general } \\
\text { physicians } \\
\mathrm{n}(\%)\end{array}$} & \multicolumn{2}{|l|}{$\begin{array}{l}\text { Referred } \\
\text { by other } \\
\text { physicians }\end{array}$} \\
\hline & & n (\%) & $P$ value \\
\hline A. General \& Unspecified & $35(20.7)$ & $26(10.9)$ & 0.007 \\
\hline $\begin{array}{l}\text { B. Blood, Blood Forming } \\
\text { Organs \& Immune Mechanism }\end{array}$ & $11(6.5)$ & $11(4.6)$ & 0.505 \\
\hline D. Digestive & $20(11.8)$ & $20(8.4)$ & 0.311 \\
\hline F. Eye & $0(0)$ & $2(0.8)$ & 0.514 \\
\hline H. Ear & $6(3.6)$ & $6(2.5)$ & 0.564 \\
\hline K. Cardiovascular & $6(3.6)$ & $14(5.9)$ & 0.356 \\
\hline L. Musculoskeletal & $21(12.4)$ & $29(12.1)$ & 1.000 \\
\hline N. Neurological & $10(5.9)$ & $18(7.5)$ & 0.558 \\
\hline P. Psychological & $31(18.3)$ & $69(28.9)$ & 0.019 \\
\hline R. Respiratory & $11(6.5)$ & $10(4.2)$ & 0.364 \\
\hline S. Skin & $3(1.8)$ & $10(4.2)$ & 0.254 \\
\hline T. Endocrine/Metabolic \& Nutritional & $8(4.7)$ & $8(3.3)$ & 0.606 \\
\hline U. Urological & $2(1.2)$ & $6(2.5)$ & 0.478 \\
\hline $\begin{array}{l}\text { W. Pregnancy, Childbearing, } \\
\text { Family Planning }\end{array}$ & $0(0)$ & $0(0)$ & NA \\
\hline X. Female Genital (including breasts) & $3(1.4)$ & $4(1.7)$ & 1.000 \\
\hline Y. Male Genital & $0(0)$ & $0(0)$ & NA \\
\hline Z. Social Problems & $0(1.4)$ & $3(1.3)$ & 0.270 \\
\hline Uncertain diagnosis & $2(1.4)$ & $3(1.3)$ & 1.000 \\
\hline Total & 169 & 239 & \\
\hline
\end{tabular}

Data were analyzed by Fisher's exact test with a post hoc Bonferroni test and significance was accepted at $P<0.0028$. NA: not available.

General physicians: physicians working at general internal medicine clinics.

Other physicians: physicians working at specialist clinics or hospital physicians.

failed to return for further assessment and 1 patient improved spontaneously. Among the patients referred by other physicians, 19 patients had somatoform disorder, and there was no significant difference of each disease between the two groups according to Fisher's test with a post hoc Bonferroni test (Table 4).

\section{Specialist treatment and hospitalization after diagnosis}

While 107 patients (63.3\%) completed treatment at the General Medicine Department, 44 patients (26.0\%) were referred to specialist departments of our hospital for further evaluation and treatment (Table 5). Among the patients referred by general physicians only four patients (2.4\%) were admitted to hospital, which was a significantly lower rate than that for the patients referred by other physicians $(\mathrm{P}=0.002)$ (Table 6). Their diagnoses included microscopic polyangitis, relapsing polychondritis, pneumonia, and purulent lymphadenitis in one patient each. 
Table 4 Final diagnoses of patients referred to the General Medicine Department $(n=408)$

\begin{tabular}{|c|c|c|c|c|}
\hline \multirow[t]{2}{*}{ ICPC-2 } & \multirow[t]{2}{*}{ Diagnosis } & \multirow{2}{*}{$\begin{array}{l}\text { Referred } \\
\text { by general } \\
\text { physicians } \\
\mathrm{n}(\%)\end{array}$} & \multirow{2}{*}{$\begin{array}{l}\text { Referred } \\
\text { by other } \\
\text { physicians } \\
\text { n (\%) }\end{array}$} & \multirow[b]{2}{*}{$P$ value } \\
\hline & & & & \\
\hline \multirow[t]{5}{*}{$\begin{array}{l}\text { A. General \& } \\
\text { Unspecified }\end{array}$} & $\begin{array}{l}\text { Unspecified viral } \\
\text { infectious } \\
\text { disease }\end{array}$ & $9(5.3)$ & $4(1.7)$ & 0.047 \\
\hline & $\begin{array}{l}\text { Conditions } \\
\text { within the } \\
\text { normal range }\end{array}$ & $8(4.7)$ & $10(4.2)$ & 0.811 \\
\hline & $\begin{array}{l}\text { Adverse } \\
\text { reactions to } \\
\text { medical } \\
\text { products }\end{array}$ & $8(4.7)$ & $3(1.3)$ & 0.058 \\
\hline & $\begin{array}{l}\text { Infectious } \\
\text { mononucleosis }\end{array}$ & $3(1.8)$ & $1(0.4)$ & 0.070 \\
\hline & Other & $7(4.1)$ & $8(3.3)$ & 0.791 \\
\hline \multirow{3}{*}{$\begin{array}{l}\text { B. Blood, Blood } \\
\text { Forming Organs } \\
\text { \& Immune } \\
\text { Mechanism }\end{array}$} & $\begin{array}{l}\text { Acute } \\
\text { lymphadenitis }\end{array}$ & $4(2.4)$ & $4(1.7)$ & 0.498 \\
\hline & $\begin{array}{l}\text { Adult Still's } \\
\text { disease }\end{array}$ & $0(0)$ & $3(1.3)$ & 0.270 \\
\hline & Other & $7(4.1)$ & $4(1.7)$ & 0.213 \\
\hline \multirow[t]{3}{*}{ D. Digestive } & $\begin{array}{l}\text { Reflux } \\
\text { esophagitis }\end{array}$ & $3(1.8)$ & $3(1.3)$ & 0.695 \\
\hline & $\begin{array}{l}\text { Acute } \\
\text { gastroenteritis }\end{array}$ & $1(0.6)$ & $3(1.3)$ & 0.645 \\
\hline & Other & $16(9.5)$ & $16(6.7)$ & 0.351 \\
\hline \multirow[t]{2}{*}{ H. Ear } & $\begin{array}{l}\text { Benign } \\
\text { paroxysmal } \\
\text { positional } \\
\text { vertigo }\end{array}$ & $3(1.8)$ & $3(1.3)$ & 0.695 \\
\hline & Other & $3(1.8)$ & $3(1.3)$ & 0.695 \\
\hline \multirow[t]{2}{*}{ K. Cardiovascular } & $\begin{array}{l}\text { Cerebrovascular } \\
\text { disease }\end{array}$ & $0(0)$ & $4(1.7)$ & 0.145 \\
\hline & Other & $6(3.6)$ & $10(4.2)$ & 0.802 \\
\hline \multirow[t]{3}{*}{ L. Musculoskeletal } & $\begin{array}{l}\text { Cervical } \\
\text { spondylosis } \\
\text { deformans }\end{array}$ & $3(1.8)$ & $4(1.7)$ & 1.000 \\
\hline & $\begin{array}{l}\text { Rheumatoid } \\
\text { arthritis }\end{array}$ & $1(0.6)$ & $3(1.3)$ & 0.645 \\
\hline & Other & $17(10.1)$ & $22(9.2)$ & 0.865 \\
\hline N. Neurological & Other & $10(5.9)$ & $18(7.5)$ & 0.558 \\
\hline \multirow[t]{7}{*}{ P. Psychological } & Anxiety disorder & $9(5.3)$ & $10(4.2)$ & 0.638 \\
\hline & Mood disorder & $6(3.6)$ & $14(5.9)$ & 0.356 \\
\hline & $\begin{array}{l}\text { Adjustment } \\
\text { disorder }\end{array}$ & $5(3.0)$ & $6(2.5)$ & 0.767 \\
\hline & $\begin{array}{l}\text { Somatoform } \\
\text { disorder }\end{array}$ & $4(2.4)$ & $19(7.9)$ & 0.016 \\
\hline & $\begin{array}{l}\text { Delusional } \\
\text { disorder }\end{array}$ & $1(0.6)$ & $4(1.7)$ & 0.409 \\
\hline & Hypochondria & $0(0)$ & $6(2.5)$ & 0.044 \\
\hline & Other & $6(3.6)$ & $10(4.2)$ & 0.802 \\
\hline
\end{tabular}

Table 4 Final diagnoses of patients referred to the General Medicine Department $(n=408)$ (Continued)

\begin{tabular}{lllll}
\hline R. Respiratory & $\begin{array}{l}\text { Cough variant } \\
\text { asthma }\end{array}$ & $0(0)$ & $3(1.3)$ & 0.270 \\
& Other & $11(6.5)$ & $7(2.9)$ & 0.092 \\
S. Skin & Cellulitis & $1(0.6)$ & $5(2.1)$ & 0.408 \\
& Stasis dermatitis & $0(0)$ & $3(1.3)$ & 0.270 \\
& Other & $2(1.2)$ & $2(0.8)$ & 1.000 \\
$\begin{array}{l}\text { T. Endocrine/ } \\
\text { Metabolic \& }\end{array}$ & Graves' disease & $3(1.8)$ & $2(0.8)$ & 0.653 \\
$\begin{array}{l}\text { Nutritional } \\
\text { U. Urological }\end{array}$ & Other & $5(3.0)$ & $6(2.5)$ & 0.767 \\
& Othelonephritis & $0(0)$ & $4(1.7)$ & 0.145 \\
$\begin{array}{l}\text { X. Female Genital } \\
\text { (including breasts) }\end{array}$ & Other & $2(1.2)$ & $2(0.8)$ & 1.000 \\
Z. Social Problems & Other & $3(1.8)$ & $4(1.7)$ & 1.000 \\
Other & $\begin{array}{l}\text { Uncertain } \\
\text { diagnosis }\end{array}$ & $0(1.4)$ & $3(1.3)$ & 0.270 \\
& $2(1.2)$ & $3(1.3)$ & 1.000
\end{tabular}

(Diagnosis with more than three patients in any group are shown, and diagnosis with less than two are included as other in its category). Date was analysed by the Fisher's exact test and post hoc Bonferroni test, and the significant level was set at $\mathrm{P}<0.0013$.

General physicians: physicians working at general internal medicine clinics. Other physicians: physicians working at specialist clinics or hospital physicians.

\section{Discussion}

In the present study, patients who were referred to a General Medicine Department because of difficulty in making a diagnosis had symptoms for 2 months on average. This suggests that a general outpatient department is likely to attract patients who have chronic diseases that do not require hospitalization but are difficult to diagnose and need to be investigated while considering a wide range of possibilities. We will discuss the characteristics of the diseases involved and the reasons for referral of these patients to the General Medicine Department by general physicians.

Table 5 Specialist treatment after diagnosis $(n=408)$

\begin{tabular}{lllc}
\hline Treated by & $\begin{array}{l}\text { Referred } \\
\text { by general physicians } \\
\mathbf{n}(\%)\end{array}$ & $\begin{array}{l}\text { Referred by } \\
\text { other physicians } \\
\mathbf{n}(\%)\end{array}$ & P value \\
\hline $\begin{array}{l}\text { General Medicine } \\
\text { Department }\end{array}$ & $107(63.3 \%)$ & $120(50.2 \%)$ & 0.011 \\
$\begin{array}{l}\text { Specialist } \\
\text { departments }\end{array}$ & $44(26.0 \%)$ & $82(34.3 \%)$ & 0.082 \\
$\begin{array}{l}\text { Other medical } \\
\text { institutions }\end{array}$ & $18(10.7 \%)$ & $37(15.5 \%)$ & 0.186 \\
\hline $\begin{array}{l}\text { Data were analyzed by Fisher's exact test and significance was accepted } \\
\text { at P<0.05. } \\
\text { General physicians: physicians working at general internal medicine clinics. } \\
\text { Other physicians: physicians working at specialist clinics or hospital physicians. }\end{array}$
\end{tabular}


Table 6 Hospitalization after diagnosis $(n=408)$

\begin{tabular}{llll}
\hline & $\begin{array}{l}\text { Referred by } \\
\text { general physicians } \\
\mathbf{n}(\%)\end{array}$ & $\begin{array}{l}\text { Referred by } \\
\text { other physicians } \\
\mathbf{n}(\%)\end{array}$ & P value \\
\hline Hospitalized & $4(2.4 \%)$ & $24(10.0 \%)$ & 0.002 \\
$\begin{array}{l}\text { Managed as an } \\
\text { Outpatient }\end{array}$ & $165(97.6 \%)$ & $215(90.0 \%)$ & 0.002 \\
\hline $\begin{array}{l}\text { Data were analyzed by Fisher's exact test and significance was accepted } \\
\text { at P }<\text { 0.05. }\end{array}$ \\
$\begin{array}{l}\text { General physicians: physicians working at general internal medicine clinics. } \\
\text { Other physicians: physicians working at specialist clinics or hospital physicians. }\end{array}$
\end{tabular}

Classification of the final diagnoses of the patients general physicians referred to the General Medicine Department by organ system according to ICPC-2 revealed that "General \& Unspecified" conditions was the most frequent diagnostic category, among which the most frequent diagnoses were normality, unspecified viral infections, and adverse reactions to medications. Patients who are actually normal and those with unspecified viral infections are unlikely to have any specific findings, so diagnosis often involves excluding a wide range of diseases. According to a report from Australia, adverse reactions to medications were detected in $10 \%$ of patients consulting general practitioners over a 6-month period, and the incidence was especially high among elderly patients [10]. Physicians should keep this in mind when making a differential diagnosis, since adverse reactions can be improved by discontinuing/switching the causative drug. In general, patients with benign diseases such as viral infections have nonspecific symptoms at an early stage, so that primary care physicians often need time to make a diagnosis. However, Japanese patients have a preference for attending large hospital because of accessibility, so patients and/or family members might request referral to a university hospital before their general physicians can make a diagnosis [11].

"Psychological" conditions was the second most frequent category. A possible reason for this high frequency of "Psychological" conditions may be that patients with psychological problems often consult general physicians or specialist departments other than the Department of Psychiatry while complaining of physical symptoms. It has been reported that patients with depression and anxiety disorders diagnosed at primary care clinics often only complain of physical symptoms $[12,13]$. Thus, patients with psychiatric diseases who present with physical symptoms may frequently be referred to a general outpatient department since their underlying diseases cannot be identified by investigations for organic illnesses. In addition, it was reported that patients with neurological diseases (such as Parkinson's disease, Alzheimer disease, or cerebrovascular disease), infections (such as human immunodeficiency virus), endocrine/metabolic diseases, cancer, and collagen diseases have a high frequency of mood disorder $[14,15]$. This adds another layer of difficulty to the diagnosis of psychological diseases because physicians have to consider the possible coexistence of a wide range of organic diseases.

Among "Musculoskeletal" conditions, which was the third major category, polymyalgia rheumatica and connective tissue diseases can be difficult to diagnose, but common diseases such as cervical spondylosis were also missed. In Western countries, it is estimated that approximately $20 \%$ of patients attending primary care clinics complain of musculoskeletal symptoms. [16,17] In Japan, Tanaka reviewed several nationwide studies of the symptoms and diseases handled by primary care clinics, and reported that diseases related to pain and arthritis were always frequent, indicating that primary care physicians need to have sufficient knowledge and skill in the orthopedic field [9].

The types of patients under management and the specialty fields differ between general physicians and other physicians, suggesting that the diseases these doctors find difficult to diagnose might also differ. A comparison between referrals from general physicians and referrals from other physicians showed that the frequency of "Psychological" conditions (especially somatoform disorder) were somewhat more frequent among patients referred by other physicians, suggesting that specialists also have difficulty in diagnosing patients with various symptoms and no abnormalities related to their specialties, in whom it is necessary to exclude diseases from other fields. However, the categories of "Psychological," "General \& Unspecified," and "Musculoskeletal" conditions were common in both groups, and no significant differences were found. In Japan, there is no national recognition of general practitioners, unlike the United Kingdom and many other countries. It seems that some specialists who formerly worked in Japanese hospitals are now providing primary care as general physicians without having received psychiatric and orthopedic training. This suggests that, even though the clinical setting differs somewhat between general physicians and other physicians, both group encounter difficulty with a similar range of diagnoses.

In the present study, very few of the patients referred by general physicians needed hospitalization and only 30\% needed specialist referral. Thus, Japanese general physicians have difficulty in diagnosing mild conditions that require exclusion of a wide range of diseases. A questionnaire study of Japanese and American residents revealed that Japanese clinical training was predominantly focused on inpatients [18]. It was also reported that Japanese general physicians want more outpatient training rather than inpatient training in order to improve their clinical skills for primary 
care [19]. To improve the diagnostic performance of physicians, further education at outpatient departments and clinics is required. It is also possible that general physicians do not perform an adequate gatekeeper role in Japan and tend to refer patients who have mild diseases to large hospitals because of the preference of Japanese patients for these institutions and the free access provided by the national health system. The Japanese government has tried to address the issue of undifferentiated functions among different tiers of health care facilities. Since 1996, patients who visit a large hospital without referral have had to pay an additional charge, but the fee (about 3000 to 4000 yen) may not be high enough to deter patients from spontaneously presenting to large hospital $[7,20]$. Further development of a system to distinguish the function of clinics from those of hospitals by the government may be needed.

\section{Limitations}

Because this study was conducted at a single outpatient department, it is unclear whether the findings are widely applicable to Japanese general physicians elsewhere. Also, other factors that might influence referral, such as the patient's preference, underlying mental condition, or relationship with the referring doctor need to be investigated in future studies.

\section{Conclusion}

This study demonstrated that Japanese general physicians found it difficult to diagnose "Psychological" and "Musculoskeletal" disorders in daily practice, as well as variations within the normal range and viral infections. Since most of these conditions referred by general physicians do not require hospitalization, appropriate education at outpatient departments and clinics will be required to improve diagnostic performance among general physicians in Japan. It is also important to enhance the gatekeeper role of Japanese general physicians and to develop a healthcare system that more clearly demarcates the functions of clinics and hospitals.

\section{Competing interests}

The authors declare that they have no competing interests.

\section{Authors' contributions}

TT carried out data collection, participated in the design of the study, and performed the statistical analysis. OY, KN, $\mathrm{T}$, and TU helped with data collection and statistical analysis. MI participated in study design and helped draft the manuscript. All authors read and approved the final manuscript.

Received: 16 December 2013 Accepted: 18 July 2014

Published: 1 August 2014

\section{References}

1. Ikegami N, Campbell JC: Health care reform in Japan: the virtues of muddling through. Health Aff 1999, 18:56-75.

2. Koizumi S: The need of general internal medicine: its historical and social background. Nihon Naika Gakkai Zasshi 2003, 92:2319-2325.
3. Ferrer RH, Hambidge SJ, Maly RC: The essential role of generalists in health systems. Ann Intern Med 2005, 142:691-699.

4. Green $C$, Holden J: Diagnostic uncertainty in general practice. A unique opportunity for research? Eur J Gen Pract 2003, 9:13-15.

5. Knottnerus JA: Medical decision making by general practitioners and specialists. Fam Pract 1991, 8:305-307.

6. Ikegami N, Campbell JC: Medical care in Japan. N Engl J Med 1995, 333:1295-1299.

7. Ito M: Health insurance systems in Japan: a neurosurgeon's view. Neurol Med Chir 2004, 44:617-628.

8. Yamada T, Yoshimura M, Nagou N, Asai Y, Koga Y, Inoue Y, Hamasaki K, Mise J, Lamberts H, Okkes I: What are the common diseases and common health problems? The use of ICPC in the community-based project. Jap J Prim Care 2000, 23:80-89.

9. Tanaka K, Nomaguchi S, Matsumura S, Fukuhara S: Ranking the frequency of patient illness at primary care clinics. Jap J Prim Care 2007, 30:344-351.

10. Miller $\mathrm{GC}$, Britt HC, Valenti L: Adverse drug events in general practice patients in Australia. Med J Aust 2006, 184:321-324.

11. Sugisawa H, Nishi S: Factors related to choice of medical facilities by residents. Nihon Koshu Eisei Zasshi 1995, 42:463-471 (in Japanese).

12. Simon GE, Vonkorff M, Piccinelli M, Fullerton C, Ormel J: An international study of the relation between somatic symptoms and depression. N Eng J Med 1999, 341:1329-1335.

13. Haug $\Pi$, Mykletun A, Dahl AA: The association between anxiety, depression, and somatic symptoms in a large population: the Hunt-II study. Psychosom Med 2004, 66:845-851.

14. Evans DL, Charney DS, Lewis L, Golden RN, Gorman JM, Krishnan KR, Nemeroff CB, Bremner JD, Carney RM, Coyne JC, Delong MR, Frasure-Smith N, Glassman AH, Gold PW, Grant I, Gwyther L, Ironson G, Johnson RL, Kanner AM, Katon WJ, Kaufmann PG, Keefe FJ, Ketter T, Laughren TP, Leserman J, Lyketsos CG, McDonald WM, McEwen BS, Miller AH, Musselman D, et al: Mood disorders in the medically ill: scientific review and recommendations. Biol Psychiatry 2005, 58:175-189.

15. Chida Y: Depression and physical disease. Jpn J Clin Psychiatry 2006, 35:927-933 (in Japanese).

16. Rekola KE, Keinänen-Kiukaanniemi S, Takala J: Use of primary health services in sparsely populated country districts by patients with musculoskeletal symptoms: consultations with a physician. J Epidemiol Community Health 1993, 47:153-157.

17. Busato A, Dönges A, Herren S, Widmer M, Marian F: Health status and health care utilization of patients in complementary and conventional primary care in Switzerland-an observational study. Fam Pract 2005, 23:116-124.

18. Fetters M, Kitamura K, Mise J, Newton W, Gorenflo D, Tsuda T, Igarashi M: Japanese and United States family medicine resident physicians' attitudes about training. Gen Med 2002, 3:9-16.

19. Kiyota A, Kamegai M, Sugimori H, Ishii A, Hayashi J, Hamashima C, Sunaga T, Ikusaka M, Yosida K, Nakamura T: Practice and education in the required clinical skills for primary care. Jap J Fam Pract 2002, 9:13-21.

20. Ikegami N, Campbell JC: Japan's health care system: containing costs and attempting reform. Health Aff (Millwood) 2004, 23:26-36.

doi:10.1186/s12930-014-0009-9

Cite this article as: Tsukamoto et al:: Investigation of diseases that cause diagnostic difficulty for Japanese general physicians. Asia Pacific Family Medicine 2014 13:9. 